\title{
Respon Imun Non-Spesifik Ikan Mas (Cyprinus carpio L.) yang Diberi $\beta$-Glukan Melalui Diet Pakan
}

\author{
Non-Specific Immune Response of Goldfish (Cyprinus carpio L.) Given \\ Dietary of Feed contains $\beta$-Glucans
}

\author{
Cahyono Purbomartono $^{1 *}$, Yusuf Aditya ${ }^{2}$, Dini Siswani Mulia ${ }^{3}$, Juli \\ Rochmijati Wuliandari ${ }^{4}$, Arif Husin ${ }^{5}$ \\ ${ }_{1,2,3,4,5}$ Pendidikan Biologi, \\ Universitas Muhammadiyah Purwokerto \\ *corr-author: cpurbomartono@yahoo.com
}

\begin{abstract}
ABSTRAK
Ikan mas (Cyprinus carpio L.) merupakan ikan air tawar yang banyak dibudidayakan di Jawa Barat dan memiliki harga jual yang relatif tinggi sehingga banyak dibudidayakan secara intensif. Tingginya padat tebar dan konsumsi pakan pada budidaya intensif menyebabkan penurunan kualitas air akibat timbunan sisa pakan dan ekskresi ikan, menimbulkan stress sehingga ikan mudah terserang penyakit. Penyakit yang sering menyerang ikan air tawar adalah Motile Aeromonas Septicemia (MAS), disebabkan oleh Aeromonas hydrophila. Untuk mengatasinya, pada umumnya dilakukan pengobatan dengan antibiotik, namun dapat mengakibatkan resistensi bakteri sehingga perlu alternatif lain. Salah satu alternatif adalah penggunaan $\beta$-glucan dari ekstraksi ragi roti Saccaromyces cerevisiae untuk meningkatkan imunitas ikan. Penelitian ini bertujuan untuk mengetahui pengaruh penggunaan $\beta$-glucan terhadap respon imun non-spesifik pada ikan mas. Penelitian ini menggunakan metode eksperimen dengan rancangan acak lengkap (RAL) terdiri atas 5 perlakuan dan 3 ulangan. Dosis $\beta$-glucan yang digunakan 0 g, 2,5 g, 5 g, 7,5 dan $10 \mathrm{~g}$ per $\mathrm{kg}$ pakan. Parameter yang diamati yaitu diferensial leukosit meliputi persentase limfosit, monosit dan neutrofil serta aktivitas fagositosis. Analisis data menggunakan Analisis of Varians (ANOVA) dengan tingkat kepercayaan 95\% dilanjutkan dengan uji Duncan Multiple Range Test (DMRT) untuk melihat pengaruh antar perlakuan. Hasil penelitian menunjukkan bahwa penambahan $\beta$-glucan melalui pakan berpengaruh signifikan terhadap persentase limfosit, peresentase neutrofil dan aktivitas fagositosis namun tidak berpengaruh signifikan terhadap persentase monosit. Dosis optimum untuk meningkatkan respon imun non-spesifik ikan mas yaitu $5 \mathrm{~g} / \mathrm{kg}$ pakan.
\end{abstract}

Kata kunci: Ikan mas (Cyprinus carpio L.), imunostimulan, $\beta$-glucan, imun non-spesifik

\begin{abstract}
Carp (Cyprinus carpio L.) is a freshwater fish that is widely cultivated in West Java and has a relatively high price so that it is cultivated intensively. The high stocking density and feed consumption in intensive cultivation causes a decrease in water quality due to deposite of waste feed and faecal, causing stress so that fish are susceptible to disease. The disease that often attacks freshwater fish is Motile Aeromonas Septicemia (MAS), caused by Aeromonas hydrophila. To overcome this, treatment with antibiotics is generally carried out, but it can cause bacterial resistance so that another alternative is needed. One alternative is the use of $\beta$-glucan from the yeast extraction of Saccaromyces cerevisiae
\end{abstract}


bread to increase fish immunity. This study used an experimental method with a completely randomized design (CRD) consisting of 5 treatments and 3 replications. The doses of $\beta$ glucan used were $0 \mathrm{~g}, 2.5 \mathrm{~g}, 5 \mathrm{~g}, 7.5$ and $10 \mathrm{~g}$ per $\mathrm{kg}$ offeed. The parameters observed were the leucocyte differential including the percentage of lymphocytes, monocytes and neutrophils as well as phagocytic activity. Data analysis used Analysis of Variance (ANOVA) with a 95\% confidence level followed by the Duncan Multiple Range Test (DMRT) to see the effect between treatments. The results showed that the addition of $\beta$ glucan through feed had a significant effect on lymphocyte percentage, neutrophil percentage and phagocytic activity but did not significantly affect the percentage of monocytes. The optimum dose to increase the non-specific immune response of goldfish is $5 \mathrm{~g} / \mathrm{kg}$ of feed.

Keywords: Goldfish (Cyprinus carpio L.), immunostimulants, $\beta$-glucan, non-specific immunity

\section{PENDAHULUAN}

Ikan mas (Cyprinus carpio L.) merupakan jenis ikan air tawar yang banyak budidayakan di Jawa Barat, mempunyai nilai ekonomis penting dengan harga jual yang cukup tinggi. Hal ini menyebabkan ikan mas mendapat perhatian dan diminati oleh para pengusaha untuk membudidayakannya. Tingginya padat tebar dan pemberian pakan pada budidaya ikan secara intensif menyebabkan menurunya kualitas air akibat timbunan sisa pakan yang berlebihan maupun dari ekskresi ikan. Penurunan kualitas air menyebabkan ikan menjadi stress dan menurunkan daya tahan tubuh ikan, sehingga ikan mudah terserang penyakit.

Penyakit yang sering menyerang ikan air tawar termasuk ikan mas, adalah bakteri Aeromonas hydrophila yang menyebabkan penyakit Motile Aeromonas Septicemia (MAS). Penyakit ini mewabah di Indonesia pertama kali tahun 1980 di daerah Jawa Barat yang menyebabkan 82,2 ton ikan mati dalam waktu 1 bulan (Angka et al., 1982). Tambunan et al. (2011), mengemukakan bahwa infeksi Aeromonas menyebabkan $80 \%$ kematian ikan budidaya pada berbagai stadia. Ciri-ciri serangan penyakit ini adalah adanya bercak merah pada kulit, insang dan organ bagian dalam serta pembengkakan pada perut dan berisi cairan yang diikuti dengan kematian (Mangunwardoyo et al., 2010). Berbagai upaya dilakukan untuk menanggulangi penyakit MAS pada ikan budidaya antara lain dengan pemberian antibiotik. Namun penggunaan antibiotik secara terus-menerus mengakibatkan resistensi bakteri dan pencemaran lingkungan. Untuk mengatasi hal demikian, diperlukan alternatif lain seperti menggunakan imunostimmulan untuk meningkatkan sistem imun sehingga tidak mudah terserang penyakit.

Imunostimulan adalah senyawa yang mempunyai kemampuan untuk meningkatkan imunitas tubuh (Ellis, 1988). Ikan memiliki mekanisme sistem imun spesifik dan nonspesifik. Sistem imun non-spesifik ini dapat dirangsang oleh berbagai jenis imunostimulan seperti levamisole, glucan, vitamin C, lipopolisakarida dan kitosan (Hastuti, 2012). Salah satu jenis glukan adalah $\beta-1,3$ glucan yang banyak terkandung dalam dinding sel ragi roti Saccharomyces cerevisiae (Hastuti, 2012). Kelebihan dari senyawa $\beta$-glucan adalah terbukti secara ilmiah sebagai biological defense modifier (BDM) dan termasuk kategori GRAS (Generally Recognized as Safe), serta tidak memiliki toksisitas atau efek samping (Ber, 1997) dalam (Thontowi et al., 2007). $\beta$-glucan memiliki berbagai aktifitas biologis sebagai antitumor, antioksidan, antikolesterol, anti penuaan dini, dan peningkat sistem imun (Lee et al., 2001). Sementara ini laporan penggunanan $\beta$-glucan dari ragi roti sebagai imunostimulan pada ikan masih relatif sedikit. Oleh karena itu penelitian ini bertujuan 
untuk mengetahui pengaruh penggunaan glukan yang dicampur kedalam pakan untuk meningkatkan imun non-spesifik ikan mas.

\section{METODE}

Bahan utama yang digunakan dalam penelitian ini adalah ragi roti Saccharomyces cerevisiae serta ikan mas $(8-10 \mathrm{~cm})$ sebanyak 15 ekor. Bahan dan alat lainnya adalah EDTA, metanol, Giemsa 10\%, dan bakteri Aeromonas hydrophila $10^{-8} \mathrm{sel} / \mathrm{mL}$. Sedangkan peralatan meliputi disposable syringe, tabung mikrohematokrit, gelas obyek \& penutup, pipet, beker glass, labu erlenmeyer, gelas ukur, pengaduk, falcon, sentrifuse, vortex, timbangan, tabung ependof, sentrifuse, dan mikroskop. Ekstraksi $\beta$-glucan berasal dari ragi roti Saccharomyces cerevisiae dengan merk dagang Mauripan, menggunakan akuades, $\mathrm{NaOH}, \mathrm{HCl}, \mathrm{H}_{2} \mathrm{O}_{2}$, aceton dan Phosfat Buffer Saline (PBS). Untuk formulasi pakan perlakuan yang dicampur glukan menggunakan beaker glass, pengaduk, timbangan, nampan, dan sprayer.

Penelitian ini menggunakan metode eksperimen karena obyek pada penelitian ini ada yang diberi perlakuan dan ada yang tidak diberi perlakuan (kontrol). Rancangan yang digunakan yaitu Rancangan Acak Lengkap (RAL) dengan 5 perlakuan dan 3 ulangan, yaitu:

$\mathrm{P} 1=$ pakan tanpa diberi $\beta$-glucan (kontrol)

$\mathrm{P} 2=$ penambahan $\beta$-glucan pada pakan sebanyak $2,5 \mathrm{~g} / \mathrm{kg}$ pakan

$\mathrm{P} 3=$ penambahan $\beta$-glucan pada pakan sebanyak $5 \mathrm{~g} / \mathrm{kg}$ pakan

$\mathrm{P} 4=$ penambahan $\beta$-glucan pada pakan sebanyak $7,5 \mathrm{~g} / \mathrm{kg}$ pakan

$\mathrm{P} 5=$ penambahan $\beta$-glucan pada pakan sebanyak $10 \mathrm{~g} / \mathrm{kg}$ pakan

\section{Ekstraksi $\beta$-glucan}

$\beta$-glucan diperoleh dari ekstraksi ragi roti menggunakan metode Hunter et al. (2002). Ragi roti $100 \mathrm{~g}$ ditambahkan $600 \mathrm{ml} \mathrm{NaOH}$, dicampur sampai rata. Selanjutnya dipanaskan menggunakan autoclave pada suhu $115{ }^{\circ} \mathrm{C}$ selama 45 menit dan dibiarkan selama 3 jam. Kemudian disentrifuse pada $2000 \mathrm{rpm}$ selama 15 menit, disuspensikan dalam air destilasi sebanyak $600 \mathrm{ml}$, dan dicuci sebanyak 3 kali. Selanjutnya ditambahkan $500 \mathrm{ml}$ $\mathrm{HCl}(3 \%)$, disentrifuse selama 15 menit dan dicuci kembali dengan menggunakan air destilasi sebanyak 3 kali. Endapan pellet yang terakhir dicuci dengan $120 \mathrm{ml} \mathrm{H}_{2} \mathrm{O}_{2}$ (3\%) sebanyak 3 kali dengan menggunakan sentrifuse dingin pada suhu $20^{\circ} \mathrm{C}$. Selanjutnya pellet dicuci kembali menggunakan acetone $100 \%$ sebanyak 2 kali. Endapan terakhir kemudian dikeringkan dengan cara dioven pada suhu $56{ }^{\circ} \mathrm{C}$. $\beta$-glucan yang sudah kering kemudian disimpan pada lemari es sampai saatnya digunakan. Sebelum digunakan, $\beta$ glucan terlebih dahulu disuspensikan menggunakan air.

\section{Formulasi pakan perlakuan}

Ekstrak $\beta$-glucan masing-masing sesuai dosis perlakuan disuspensikan terlebih dahulu dengan cara dilarutkan dalam $10 \mathrm{~mL}$ air pada beaker glass. Campuran yang sudah homogen tersebut kemudian dimasukkan kedalam sprayer dan disemprotkan pada $1 \mathrm{~kg}$ pakan sesuai dengan dosis maising-masing. Pakan tersebut kemudian dikeringanginkan, apabila sudah kering kemudian disimpan pada suhu kamar sampai saatnya digunakan.

\section{Aklimatisasi Ikan}

Aklimatisasi ikan dilakukan selama 1 minggu di dalam wadah ember, bertujuan agar ikan beradaptasi terlebih dahulu dengan lingkungan baru maupun dengan pakan pelet yang diberikan. 


\section{Pengambilan Sampel Darah}

Pengambilan sampel darah dilakukan pada hari ke-0 (sebelum perlakuan), serta hari ke-6 dan 12 setelah ikan diberi perlakuan melalui vena caudalis. Ikan dibius terlebih dahulu menggunakan minyak cengkeh dengan dosis $1 \mathrm{ml} / 8$ liter air sampai ikan pingsan. Syringe dibasahi dengan EDTA sebagai antikoagulan, darah dihisap perlahan sebanyak 1 $\mathrm{ml}$, kemudian dipindahkan ke dalam tabung eppendof.

\section{Pengukuran imun non-spesifik}

1. Diferensial Leukosit

Pengamatan diferensial leukosit dilakukan melalui preparat ulas darah. Setetes darah dituangkan pada gelas obyek dan diulas (digeser) dengan sudut $45^{\circ}$ sehingga darah menyebar. Preparat ulas darah dibiarkan kering udara, kemudian difiksasi dengan methanol selama 10-15 menit. Selanjutnya pereparat diwarnai Gieamsa 10\% selama 30 menit, dicuci, kemudian dikeringkan. Preparat ulas darah yang telah diwarnai kemudian diamati dan kemudian dihitung di bawah mikroskop dengan pembesaran 400x sampai jumlah 100 sel leukosit.

\section{Aktivitas Fagositotis}

Uji aktifitas fagositosis dilakukan berdasarkan metode Isnansetyo et al. (2016). Darah dimasukkan dalam tabung hematokrit, disentrifuse pada kecepatan $1000 \mathrm{rpm}$ selama 5 menit. Tabung hematokrit dipotong pada batas eritrosit dan leukosit, kemudian bagian leukosit ditampung pada tabung eppendorf. Leukosit sebanyak $100 \mu \mathrm{l}$ dimasukkan pada sumuran mikroplate, kemudian ditambah dengan Aeromonas hydrophila (kepadatan $10^{8}$ $\mathrm{sel} / \mathrm{mL}$ ) dengan volume yang sama, dicampur dengan cara pipeting, kemudian diinkubasi selama 30 menit. Selanjutnya $5 \mu \mathrm{l}$ sampel diambil dan diletakkan diatas obyek glas, dibuat preparat ulas dan didiamkan hingga kering angin. Selanjutnya difiksasi dengan ethanol absolut selama 5 menit dan dikering anginkan. Setelah kering angin, selanjutnya diwarnai dengan safranin $(0,15 \%)$ selama 10 menit dan diamati dibawah mikroskop perbesaran 400x. Aktifitas fagositosis dinyatakan dengan jumlah sel yang memfagosit bakteri dibagi 100 sel fagosit yang diamati dikalikan 100\%. Data aktivitas fagositosis dianalisis mengunakan SPSS.

\section{HASIL DAN PEMBAHASAN}

Penelitian ini yaitu tentang pengaruh pemberian immunostimulan $\beta$-glucan melalui pakan terhadap respons imun non-spesifik ikan mas (Cyprinus carpio L.). Parameter utama yang digunakan pada penelitian ini yaitu parameter pemeriksaan hematologi diferensial leukosit dan aktivitas fagositosis. Differensial leukosit yang diamati adalah komponen selsel leukosit yang meliputi persentase limfosit, neutrofil dan monosit.

\section{Persentase Limfosit}

Nilai rerata persentase limfosit ikan mas setelah diberi pakan dengan penambahan $\beta$-glucan selama 12 hari berturut-turut dapat dilihat pada Tabel 1.

Tabel 1. Jumlah Persentase Limfosit (\%) hari ke-0, 6 dan 12 selama penelitian

\begin{tabular}{cccc}
\hline Perlakuan & \multicolumn{3}{c}{ Lama penelitian hari ke- } \\
\cline { 2 - 4 } & 0 & 6 & 12 \\
\hline P1 & $67,40 \pm 0,43^{\text {ab }}$ & $68,86 \pm 1,26^{\mathrm{a}}$ & $73,30 \pm 1,17^{\mathrm{a}}$ \\
P2 & $68,00 \pm 1,17^{\mathrm{ab}}$ & $70,50 \pm 2,98^{\mathrm{a}}$ & $77,33 \pm 3,83^{\mathrm{b}}$ \\
P3 & $66,70 \pm 0,28^{\mathrm{a}}$ & $68,56 \pm 3,46^{\mathrm{a}}$ & $76,93 \pm 1,18^{\mathrm{ab}}$ \\
\hline
\end{tabular}




\begin{tabular}{cccc}
\hline P4 & $67,00 \pm 0,88^{\mathrm{ab}}$ & $69,50 \pm 1,17^{\mathrm{a}}$ & $78,96 \pm 1,23^{\mathrm{b}}$ \\
P5 & $68,56 \pm 0,95^{\mathrm{b}}$ & $71,50 \pm 0,80^{\mathrm{a}}$ & $78,30 \pm 0,17^{\mathrm{b}}$ \\
\hline
\end{tabular}

Keterangan: P1: Kontrol, P2: 2,5 g/kg pakan, P3: 5 g/kg pakan, P4: 7,5 g/kg pakan, $10 \mathrm{~g} / \mathrm{kg}$ pakan. Nilai dengan superscript yang sama pada kolom menunjukkan tidak berbeda nyata pada uji DMRT dengan taraf kepercayaan 5\% (P>0,05).

Hasil analisis of variance (ANOVA) dengan uji lanjut Duncan pada taraf kepercayaan 95\% $(\mathrm{P}<0,05)$ pada hari ke-0 sebelum ikan diberi perlakuan dan hari ke-6 setelah ikan diberi perlakuan menjukan hasil bahwa P1 (kontrol) tidak berbeda nyata $(\mathrm{P}>0,05)$ dengan $\mathrm{P} 2, \mathrm{P} 3, \mathrm{P} 4$, dan $\mathrm{P} 5$. Pada hari ke-12 setelah ikan diberi perlakuan menunjukkan hasil bahwa $\mathrm{P} 1$ berbeda nyata $(\mathrm{P}<0,05)$ dengan $\mathrm{P} 2, \mathrm{P} 3, \mathrm{P} 4$ dan $\mathrm{P} 5$.

Berdasarkan data diatas dapat diketahui bahwa persentase limfosit tertinggi dicapai pada perlakuan P4 pada hari ke-12 yaitu 78,96 \%. Persentase limfosit terendah terdapat pada perlakuan P3 pada hari ke-0 sebelum ikan diberi perlakuan yaitu sebesar 66,7\%. Tabel 4.1 meperlihatkan limfosit nilainya meningkat seiring dengan waktu. Hal ini memperlihatkan bahwa perbedaan dosis ekstrak $\beta$-glucan yang dicampur kedalam pakaaan berpengaruh terhadap peningkatan persentase limfosit. Hal ini dikarenakan glucan yang masuk kedalam tubuh ikan dapat merangsang makrofag untuk memproduksi interleuktin (IL) yang kemudian menginduksi sel limfosit menjadi aktif. Sel limfosit kemudian akan membelah menjadi sel Limfosit T dan Limfosit B (Purbomartono et al., 2019) sehingga persentase limfosit dalam darah meningkat. Sel limfosit B mempunyai kemampuan untuk bertransformasi menjadi sel plasma yaitu sel yang meproduksi antibodi. Sedangkan sel limfosit $\mathrm{T}$ berperan dalam mengontrol respons imun (Ayuningtyas, 2012).

Pada penelitian ini persentase limfosit lebih besar dibandingkan persentase neutrofil dan monosit karena proporsinya lebih besar dalam sirkulasi darah. Limfosit pada awalnya bersifat tidak aktif dan baru aktif dalam memproduksi antibodi apabila ada rangsangan dari antigen atau imunostimulan. Stimulus ini menyebabkan limfosit berproliferasi dan berdiferensiasi menjadi limfosit B \& T. Selanjutnya limfosit B berdiferensiasi menjadi sel plasma dan sel memori untuk membentuk antibodi spesifik dan kontrol mekanisme imunitas sesuai dengan antigen atau imunostimulan yang memberikan stimulus tersebut. Sedangkan limfosit $\mathrm{T}$ berperan dalam merangsang makrofag untuk berperan aktif dalam mekanisme fagositosis (Purbomartono, 2019).

\section{Persentase Neutrofil}

Nilai rerata persentase neutrofil ikan mas setelah diberi pakan dengan penambahan $\beta$-glucan selama 12 hari berturut-turut dapat dilihat pada Tabel 2.

Tabel 2. Jumlah Persentase Neutrofil (\%) pada hari ke-0, 6 dan 12 selama penelitian

\begin{tabular}{cccc}
\hline Perlakuan & \multicolumn{3}{c}{ Lama penelitian hari ke- } \\
\cline { 2 - 4 } & 0 & 6 & 12 \\
\hline P1 & $11,60 \pm 1,85^{\mathrm{a}}$ & $20,77 \pm 6,04^{\mathrm{b}}$ & $7,90 \pm 0,43^{\mathrm{a}}$ \\
P2 & $13,96 \pm 0,55^{\mathrm{ab}}$ & $19,40 \pm 2,36^{\mathrm{b}}$ & $11,43 \pm 2,81^{\mathrm{a}}$ \\
P3 & $12,60 \pm 2,35^{\mathrm{ab}}$ & $15,63 \pm 1,65^{\mathrm{ab}}$ & $19,40 \pm 5,14^{\mathrm{b}}$ \\
P4 & $14,16 \pm 1,40^{\mathrm{ab}}$ & $9,13 \pm 1,40^{\mathrm{a}}$ & $19,90 \pm 2,50^{\mathrm{b}}$ \\
P5 & $14,60 \pm 0,45^{\mathrm{b}}$ & $15,50 \pm 4,15^{\mathrm{ab}}$ & $22,87 \pm 1,95^{\mathrm{b}}$ \\
\hline
\end{tabular}


Keterangan: P1: Kontrol, P2: 2,5 g/kg pakan, P3: $5 \mathrm{~g} / \mathrm{kg}$ pakan, P4: 7,5 g/kg pakan, $10 \mathrm{~g} / \mathrm{kg}$ pakan. Nilai dengan superscript yang sama pada kolom menunjukkan tidak berbeda nyata pada uji DMRT dengan kepercayaan 5\% (P>0,05).

Hasil analisis of varians (ANOVA) dengan uji lanjut Duncan pada taraf kepercayaan 95\%, memperlihatkan hasil bahwa pada hari ke-0 sebelum ikan diberi perlakuan, P1 (kontrol) tidak berbeda nyata $(\mathrm{P}>0,05)$ dengan $\mathrm{P} 2, \mathrm{P} 3$, dan $\mathrm{P} 4$. Demikian pula pada ke-6 setelah ikan diberi perlakuan, P1 menunjukkan hasil tidak berbeda nyata ( $>0$,05) dengan P2, P3, P4, dan P5. Sedangkan hari ke-12 setelah ikan diberi perlakuan menunjukkan hasil bahwa $\mathrm{P} 1$ berbeda nyata $(\mathrm{P}<0,05)$ dengan $\mathrm{P} 2, \mathrm{P} 3, \mathrm{P} 4$ dan $\mathrm{P} 5$. Hasil ini membuktikan bahwa pemberian $\beta$-glucan melalui pakan dengan dosis yang berbeda mampu meningkatkan persentase persentase neutrofil secara signifikan. Persentase

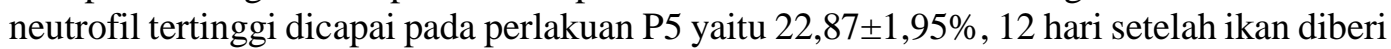
perlakuan. Persentase neutrofil terendah terdapat pada perlakuan P1 yaitu 11,6\% sebelum ikan diberi perlakuan. Persentase neutrofil dalam penelitian ini berkisar antara 7,90-22,87 $\%$.

Berdasarkan Tabel 4.2 menunjukkan peningkatan neutrofil terjadi pada hari ke-6 pada P1, P2, P3 dan P5 sedangkan pada perlakuan P4 nilainya cenderung menurun. Pada hari ke-12 peningkatan persentase neutrofil terjadi pada perlakuan P3, P4, dan P5 sedangkan pada perlakuan P1 dan P2 nilainya cenderung menurun. Peningkatan jumlah neutrofil dalam darah diduga karena meningkatnya produksi pada pusat organ limfoid yaitu ginjal, timus dan limpa untuk menghasilkan sel-sel fagosit yang diduga terdapat infeksi ringan. Menurut Tizard (1988), fungsi utama neutrofil adalah penghancuran bahan asing melalui proses fagositosis. Mediator fagositosis difasilitasi oleh kemotaksis, menyebabkanneutrofil bermigrasi menuju partikel, pelekatan partikel pada sel, penelanan partikel oleh sel, dan penghancuran partikel oleh enzim lisosim didalam fagolisosom. Ketika serangan benda asing berhasil difagositosis oleh neutrofil, mengakibatkan sel neutrofil menjadi berkurang. Hal ini dikarenakan menurut Jain (1993), setelah proses infeksi berakhir jumlah neutrofil dapat ditekan. Sel-sel yang mati pada jaringan nekrotik yang mengandung neutrofil secara bertahap mengalami lisis dalam beberapa hari. Life span (waktu paruh, umur) neutrofil yang pendek diduga mengakibatkan nilai persentase neutrofil yang fluktuatif pada penelitian ini. Hal ini sesuai dengan pendapat Tizard (1988) yang menyatakan bahwa neutrofil merupakan garis pertahanan pertama yang bergerak cepat kearah bahan asing termasuk imunostimulan, kemudian segera mengeliminasikanya. Namun karena tidak mampu bertahan lama sehingga nilainya lebih fluktuatif dalam sirkulasi darah. Sedangkan sel fagosit dari mononuklear (monosit atau makrofag) kerjanya lamba namun mampu bertahan lama, sehingga dapat mefagosit berulang-ulang dan dapat mengolah antigen untuk proses tanggap kebal.

\section{Persentase Monosit}

Hasil analisis of variance (Anova) dengan uji lanjut Duncan pada taraf kepercayaan 95\% $(\mathrm{P}<0,05)$ diperoleh hasil bahwa $\mathrm{P} 1$ (kontrol) tidak berbeda nyata ( $>00,05$ ) dengan P2, P3, P4, dan P5 baik pada hari ke-0 (sebelum ikan diberi perlakuan) maupun pada hari ke-6 dan hari ke-12 setelah ikan diberi perlakuan. Berdasarkan data diatas dapat diketahui bahwa persentase monosit tertinggi dicapai pada perlakuan $\mathrm{P} 4$ yaitu 4,3\% pada hari ke- 0 (sebelum ikan diberi perlakuan). Persentase monosit terendah terdapat pada hari ke 12 perlakuan P4 1,53 $\pm 0,23 \%$. Persentase monosit pada penelitian ini berkisar antara $1,53-4,30 \%$.

Nilai rerata persentase monosit ikan mas setelah diberi pakan dengan penambahan $\beta$-glucan selama 12 hari berturut-turut dapat dilihat pada Tabel 3. 
Tabel 3. Jumlah Persentase Monosit (\%) pada hari ke- 0,6 dan 12 selama penelitian

\begin{tabular}{cccc}
\hline Perlakuan & \multicolumn{3}{c}{ Lama penelitian hari ke- } \\
\cline { 2 - 4 } & 0 & 6 & 12 \\
\hline P1 & $3,70 \pm 0,10^{\mathrm{ab}}$ & $3,63 \pm 0,78^{\mathrm{a}}$ & $2,00 \pm 0,55^{\mathrm{a}}$ \\
P2 & $4,03 \pm 0,25^{\mathrm{ab}}$ & $2,, 20 \pm 0,00^{\mathrm{a}}$ & $1,63 \pm 0,20^{\mathrm{a}}$ \\
P3 & $3,87 \pm 0,21^{\mathrm{ab}}$ & $2,30 \pm 1,56^{\mathrm{a}}$ & $2,33 \pm 0,65^{\mathrm{a}}$ \\
P4 & $4,30 \pm 0,46^{\mathrm{b}}$ & $1,67 \pm 0,55^{\mathrm{a}}$ & $1,53 \pm 0,23^{\mathrm{a}}$ \\
P5 & $3,43 \pm 0,50^{\mathrm{a}}$ & $2,57 \pm 1,53^{\mathrm{a}}$ & $1,60 \pm 0,17^{\mathrm{a}}$ \\
\hline
\end{tabular}

Keterangan: P1: Kontrol, P2: 2,5 g/kg pakan, P3: 5 g/kg pakan, P4: 7,5 g/kg pakan, $10 \mathrm{~g} / \mathrm{kg}$ pakan. Nilai dengan superscript yang sama pada kolom menunjukkan tidak berbeda nyata pada uji DMRT dengan taraf kepercayaan $5 \%(\mathrm{P}>0,05)$.

Hasil penelitian memperlihatkan bahwa pemberian $\beta$-glucan tidak meningkatkan persentase monosit. Pada hari ke-6 dan ke-12 persentase monositnya tidak mengalami peningkatan, hal ini diduga karena tidak dilakukan uji tantang menggunakan bakteri sehingga ikan tidak mengalami infeksi. Pendapat senada dilaporkan Moyle \& Cech (2004), yang menyatakan bahwa jumlah monosit didalam populasi sel darah putih sedikit, namun jumlahnya akan meningkat jika ada infeksi pada jaringan. Hal serupa juga dilaporkan Vonti (2008), bahwa nilai monosit lebih tinggi dari kisaran normal diduga karena kondisi ikan yang stress. Jumlah monosit dapat meningkat sekitar 38\% dalam waktu singkat bila terjadi infeksi (Mahasri et al., 2011).

Penurunan persentase monosit pada hari ke-6 dan ke-12 diduga terjadi karena monosit sudah mengalami diferensiasi menjadi makrofag sehingga terdeteksi rendah persentasinya didalam serkulasi darah. Menurut (Fujaya, 2004), monosit merupakan prekursor dari makrofag. Monosit yang sudah berdiferensiasi menjadi makrofag akan meninggalkan aliran darah dan bergerak menuju jaringan. Menurut Angka (2005), makrofag berada didalam jaringan sebagai pelindung tubuh, juga pemakan sel bakteri dan sisa (debris), sedangkan monosit merupakan leukosit yang masih berada didalam sirkulasi darah. Monosit lebih kuat dalam memfagosit dibandingkan dengan neutrofil bahkan mampu mefagosit partikel yang lebih besar dalam jumlah yang lebih banyak. Makrofag yang merupakan monosit matang mampu memfagosit 100 sel bakteri sedangkan sel neutrofil mampu memfagosit 5-20 sel bakteri sebelum menjadi tidak aktif dan mati (Fujaya, 2004).

\section{Aktifitas Fagositosis}

Nilai rerata aktivitas fagositosis ikan mas setelah diberi pakan dengan penambahan $\beta$-glucan selama 12 hari berturut-turut dapat dilihat pada Tabel 4.

Tabel 4 Jumlah Aktivitas Fagositosis (\%) pada hari ke-0, 6 dan 12 selama penelitian

\begin{tabular}{cccc}
\hline Perlakuan & \multicolumn{3}{c}{ Lama penelitian hari ke- } \\
\cline { 2 - 4 } & 0 & 6 & 12 \\
\hline P1 & $13,00 \pm 2,64^{\mathrm{a}}$ & $11,33 \pm 3,05^{\mathrm{a}}$ & $20,33 \pm 6,51^{\mathrm{a}}$ \\
P2 & $23,00 \pm 4,58^{\mathrm{b}}$ & $20,33 \pm 4,51^{\mathrm{b}}$ & $22,00 \pm 6,00^{\mathrm{a}}$ \\
P3 & $18,67 \pm 4,16^{\mathrm{ab}}$ & $22,67 \pm 6,03^{\mathrm{b}}$ & $24,67 \pm 6,03^{\mathrm{a}}$ \\
P4 & $19,67 \pm 7,02^{\mathrm{ab}}$ & $19,00 \pm 4,36^{\mathrm{ab}}$ & $25,33 \pm 3,51^{\mathrm{a}}$ \\
P5 & $19,33 \pm 5,50^{\mathrm{ab}}$ & $15,00 \pm 4,36^{\mathrm{ab}}$ & $25,00 \pm 2,00^{\mathrm{a}}$ \\
\hline
\end{tabular}


Keterangan: P1: Kontrol, P2: 2,5 g/kg pakan, P3: $5 \mathrm{~g} / \mathrm{kg}$ pakan, P4: 7,5 g/kg pakan, $10 \mathrm{~g} / \mathrm{kg}$ pakan. Nilai dengan superscript yang sama pada kolom menunjukkan tidak berbeda nyata pada uji DMRT dengan taraf kepercayaan 5\% (P>0,05).

Hasil perhitungan ANOVA pada taraf kepercayaan 95\% $(\mathrm{P}<0,05)$ diperoleh hasil bahwa $\mathrm{P} 1$ (kontrol) tidak berbeda nyata $(\mathrm{P}>0,05)$ dengan $\mathrm{P} 3$, $\mathrm{P} 4$, dan $\mathrm{P} 5$ pada hari ke-0 (sebelum diberi perlakuan). Namun setelah ikan diberi perlakuan sampai hari ke-6, hasil uji Duncan menunjukkan bahwa P1 (Kontrol) berbeda nyata dengan P2, dan P3. Sedangkan pada hari ke-12 memperlihatkan terjadi peningkatan aktivitas fagositosis dibanding kontrol, namun tidak signifikan.

Peningkatan nilai aktivitas fagositosis pada hari ke-6 menunjukkan pemberian glucan dalam penelitian ini berpengaruh secara signifikan terhadap peningkatan aktivitas fagositosis. Peningkatan yang sama terjadi pada hari ke-12 namun tidak signifikan dibanding kontrol. Hal ini sesuai dengan pendapat Amrullah (2005) yang menyatakan bahwa pola peningkatan persentase indeks fagositosis merupakan fungsi dari peningkatan total leukosit maupun persentasenya baik pada limfosit, monosit, dan neutrofil. Berkaitan dengan fungsi fagositosis, peningkatan aktivitas fagositik tersebut disebabkan terutama karena jumlah maupun kemampuan sel-sel fagositik seperti makrofag dan neutrofil diduga meningkat. Baik makrofag maupun neutrofil berfungsi untuk menghancurkan bahan asing melalui proses fagositosis sehingga jika persentase makrofag dan neutrofil meningkat maka juga akan meningkatkan aktivitas fagositosis. Hal ini sejalan dengan pendapat Tizard (1988), yang menyatakan bahwa fungsi utama neutrofil adalah untuk penghancuran bahan asing melalui proses fagositosis yang didahului dengan mekanisme kemotaksis sel bermigrasi menuju partikel, pelekatan partikel, dan penghancuran partikel oleh enzim lisosim didalam fagolisosom. Menurut Raa et al. (1992) pabila glucan masuk ke dalam tubuh, glucan ini akan merangsang makrofag untuk memproduksi interleukin yang kemudian akan memberikan rangsangan untuk mengaktifkan limfosit. Limfosit akan mengalami pembelahan menjadi limfosit $T$ dan limfosit $B$. Sel limfosit $T$ akan memproduksi lebih banyak interferon (limfokin) yang akan mengaktifkan makrofag kembali, sehingga meningkatkan kemampuannya memfagosit bakteri, virus, dan benda asing lainnya (Raa et al., 1992). Raa (2000) menambahkan bahwa $\beta$-glucan yang terdapat dalam ragi roti dapat mengikat pada molekul reseptor yang terdapat pada permukaan selsel fagosit. Pada saat reseptor berikatan dengan $\beta$-glucan maka sel fagosit akan menjadi lebih aktif dalam melakukan fagositosis terhadap partikel asing atau bakteri. Dengan adanya peningkatan jumlah aktivitas fagositosis ini menunjukkan terjadi peningkatan imunitas tubuh ikan.

Pada bagian lain, aktifitas fagositosis yang rendah dapat disebabkan oleh kontaminan, stress, infeksi kronis, kekurangan protein dan vitamin. Penurunan aktivitas fagositosis hari ke-6 pada P4 (19\%) \& P5 (15\%) diduga terjadi karena adanya infeksi alami atau faktor stress yang menyababkan penekanan pada sistem imun. Namun aktivitas fagositosis meningkat kembali seiring dengan lamanya waktu pemberian $\beta$-glucan yaitu pada hari ke-12. Hal ini dikarenakan $\beta$-glucan diketahui memiliki aktivitas dalam meningkatkan fungsi sistim imun inang, dan mengaktifkan makrofag serta neutrofil melalui pengikatan dengan reseptor $\beta$-glucan (Lee et al., 2001).

Proses fagositosis menurut Spector (1993) dalam Hastuti (2012) terjadi apabila ada kontak antara partikel dengan permukaan sel fagosit. Membran sel kemudian mengalami invaginasi dimana dua lengan sitoplasma menelan partikel sehingga terkurung didalam sitoplasma sel, terletak didalam vakuola yang dilapisi membran (fagosom). Lisosom yang ada didekatnya melebur ke dalam fagosom dan mengeluarkan enzim-enzim membentuk fagolisosom atau lisosom sekunder sehingga bakteri atau partikel tersebut mati dan hancur dalam sel fagosit tersebut. Proses fagositosis meliputi tahap kemotaksis, perlekatan, 
penelanan, dan pencernaan. Banyak faktor yang mempengaruhi proses fagositosis antara lain pergerakan sel fagositik karena rangsangan benda asing dan kerentanan benda asing untuk difagositosis (Kindt et al., 2007).

\section{KESIMPULAN}

Berdasarkan hasil penelitian dapat disimpulkan bahwa penambahan $\beta$-glucan melalui pakan yang diberikan pada ikan mas (Cyprimus carpio L.) selama 12 hari pemeliharaan berpengaruh nyata terhadap persentase limfosit, persentase neutrophil dan aktivitas fagositosis, tetapi tidak berpengaruh nyata terhadap persentase monosit. Sedangkan dosis $\beta$-glucan yang paling efektif untuk meningkatkan respons imun nonspesifik ikan mas (Cyprimus carpio L.) yaitu pada perlakuan P3 (5 g/kg pakan)

\section{DAFTAR PUSTAKA}

Amrullah. 2005. Penggnaan Imonosimulan Spirula platensis untuk Meningkatkan Ketahanan Tubuh Ikan Koi (Cyperus carpio) Terhadap Virus Herpes. Tesis. Sekolah Pascasajarna. Institute Pertanian Bogor. Bogor. 51.

Angka S.L. 2005. Kajian Penyakit Motile Aeromonas Septicemia (MAS) Pada Ikan Lele Dumbo (Clarias sp.) Patologi, pencegahan dan pengobatan dengan fitofarmaka. Disertasi. Sekolah Pascasarjana Institute Pertanian Bogor. Bogor.

Angka S.L., S.U. Pramono, F.H. Pasaribu, \& M. Alifuddin. 1982. Isolasi dan identifikasi jasad renik penyebab epiemi penyakit bercak merah ikan di Jawa Barat. Buletin Perikanan. Volume 1 (1):1-14.

Ayuningtyas. 2012. Pengaruh Fucoidan dari Turbinaria sp. Terhadap Pertahanan Non spesifik Nila (Oreochromis sp.). Skripsi. Yogyakarta. Fakultas Pertanian Universitas Gadjah Mada

Fujaya, Y. 2004. Fisiologi Ikan Dasar Pengembangan Teknologi Perikanan. Jakarta: Rineka Cipta.

Hastuti, S.D. 2012. Suplementasi $\beta$-glukan dari Ragi Roti (Saccharomyces cerevisiae) dalam Pakan terhadap Aktivitas Fagositosis, Aktivitas NBT, Total Protein Plasma, dan Aktivitas Aglutinasi darah Ikan Nila (Orechromis niloticus). Jurnal Perikanan, Volume 1 (3): 149-155.

Hunter, K.W. Jr., Gault, \& Berner. 2002. Preparation of Microparticulate $\beta$-Glucan from Saccharomyces cerevisiae for Use in immune potentiation. Letters in Applied Microbiology. Volume 35 (4): 267-269.

Isnansetyo, A., A. Fikriyah, N. Kasanah \& Murwantoko. 2016. Non-specific immune potentiating activity of fucoidan from a tropical brown algae (Phaeophyceae), Sargassum cristaefolium in tilapia (Oreochromis niloticus). Aquaculture International. Volume 24:465-477

Jain, N. C. 1993. Essentials of Veterinary Hematology. Philadelphia: Lea and Febiger publishing.

Kindt TJ, B.A Osborne \& R.A Goldsby. 2007. Kuby Immunology. Ed ke-6. New York: W.H. Freeman and Company.

Lee J.N, Lee D.Y. In-Hye J, Gi-Eun K., \& Kim H.N. 2001. Purification of soluble $\beta$-Glucan with

immune-enhancing activity form the cell wall of yeast. Bioscience Biotechnology and Biochemistry. Volume 65 (4): 837-841.

Mahasri G., P. Widyatusti \& L. Sulmartiwi. 2011. Gambaran Leukosit Darah Ikan Koi (Cyprinus carpio) yang Terinfestasi Ichthyophthirius multifiliis pada Derajat 
Infestasi yang Berbeda dengan Metode Kohabitasi. Jurnal Ilmiah Perikanan dan Kelautan. Volume 3 (1): 91-96

Mangunwardoyo, W., R. Ismayasari \& Riani. 2010. Uji Patogenitas dan Vierulensi Aeromonas hydrophilla Stanier pada Ikan Nila (Oreochromis Niloticus Lin.) Melalui Postulat Koch. Fakultas Perikanan dan Ilmu Kelautan, Institut Pertanian Bogor. Jurnal Ristek Akuakultur. Volume 5 (2): 245-255.

Moyle, P.B \& J.J Cech. 2004. Fishes An Introduction To Ichthyology. Fifth Edition. Prentice Hall: New Jersey.

Purbomartono, C., A. Isnansetyo, Murwantoko and Triyanto, 2019. Dietary Fucoidan from Padina boergesenii to Enhance Non-specific Immune of Catfish (Clarias sp.) Journal of Biological Sciences . Volume 19 (2): 173-180

Purbomartono, C. 2019. Respon Imun Non-Spesifik Lele Dumbo (Clarias sp.) yang Diberi Fucoidan dari Rumput Laut Cokelat (Padina sp.) Secara Oral. Disertasi. UGM Jogjakarta.

Raa, J., G. Roestad, R. Engstad \& B. Robertsen. 1992. The Use of Immunostimulan to Increase Resistance of Aquatic Organisms to Microbial Infections. In: Shariff, M., Subangsihe, R.P. and Arthur, J.R. (eds). Diseases in Asian Aquaculture I. Fish Health Section. Asian Fisheres sosiety, Manila, Philipines. Pp: 39-50.

Raa J. 2000. The use of immune-stimulant in fish and shellfish feeds. University of Thomse, Norway. Biotech ASA, Norway. Pp: 47-57

Tambunan, J.E., G. Mahasri \& K. Setiawan. 2011. Infestasi Ektoparasit Lernaea Sebagai Faktor Pemicu Munculnya Infeksi Bakteri Aeromonas pada Benih Ikan Mas (Cyprinus carpio L.). Jurnal Penelitian. Skripsi. Universitas Airlangga Surabaya.

Thontowi, A., Kusmiati, \& S. Nuswantara. 2007. Produksi Glukan Saccaromyces cerevisiae dalam Media dengan Sumber Nitrogen Berbeda Pada Air-Lift Fermentor. Biodiversitas. 8 (4): 253-256.

Tizard, I. 1988. An introduction to Veterinary Immunology. Second Ed. Philadelphia: WB. Saunders Company.

Vonti, O. 2008. Gambaran Darah Ikan Mas (Cyprinus carpio Linn) Strain Sinyonya yang Berasarl dari Daerah Ciempea-Bogor. Skripsi. Fakultas Kedokteran Hewan Institut Pertanian Bogor. Bogor. P. 60. 